\title{
Educational Management of Islamic High Boarding School 'Roudlotul Ulum'
}

\author{
Achmad Slamet \\ Universitas Islam Nahdlatul Ulama' (UNISNU) \\ Jepara, Indonesia \\ achmadslamet9@gmail.com \\ Ibnu Hadjar \\ Universitas Islam Nahdlatul Ulama' (UNISNU) \\ Jepara, Indonesia
}

\author{
Mustaqim \\ Universitas Islam Nahdlatul Ulama' (UNISNU) \\ Jepara, Indonesia
}

\begin{abstract}
Education management of Islamic High School in pesantren(Islamic Boarding School) is a part of knowledge that empowers human resources in conducting the education of Islamic senior high school in pesantren. This management needs to have serious attention and be programmed, because pesantren is the older education asset in Indonesia. The scope of this study consists of curriculum management, workforce management, student management, infrastructure management and finance management. The research was conducted in Pesantren Roudlotul Ulum, Guyangan-Pati. Raudlotul Ulum leads the merging of pesantren curriculum and Islamic Senior high school curriculum, so that it became an interesting to be studied. The method and approach of the study is a field research with qualitative method or descriptive qualitative approach. The result of this study is the merging of some curriculums; national examinations from the ministries of education and culture management (Kemendikbud), with the national standardized madrasah exam from the management of the ministry of religion (Kemenag), and the management of pesantren with munaqosah exams of local content (Mulok) Madrasah Aliyah in Raudlotul Ulum. The system of planning, organizing, implementation and evaluation is different from the management of Islamic Senior High school in general. The tree different curriculum could b applied for students in a school or boarding school to find out the best output.
\end{abstract}

Keywords—education, management, pesantren, madrasah

\section{INTRODUCTION}

Education is oriented to form intelectual and high skilled people, apparently it becomes a reality that we find in environment of our educational institutions. Circumstances, occurs in our general education environment, in the contrary the pesantren institutions- Islamic religious education only manage the science of religion.

The problems that arise in the global era, on the one hand the educational institutions (formal or informal) has more priority on science and technology and on the other hand, it prefers the science of faith and taqwa (IMTAQ), then it causes the dichotomy in which a community of learners comprehends

more on scientific knowledge, but are weak in terms of religion science [1].
If we look at the environment around us, an institution that has a large role in developing the science of religion tafaqquh fiddin - systemically is a pesantren. It is undeniable that the results of education in pesantren not only creates leaders are resilient in aqidah and worship, but more than that, it has created the figures of leaders who willingly make sacrifices for the betterment of the nation and the country.

Salaf pesantren, is a boarding institution that maintains the teaching of classical Islamic books (salaf) as the core of education. While the madrasah system is set only to facilitate sorogan system, which is used in institutions old pengajian form, without introducing the teaching of general knowledge [2].

Pesantren as the oldest education assets in Indonesia, is an institution that can be said is a form of fair process of development of national education system. From a historical point of view, it is not only identical with Islamic meaning, but also contains the meaning of Indonesian authenticity (indigenous) [3].

Pesantren has slow progress on developing the education in Indonesia, since it has survived with the Islamic education. This fact is confirmed by the presence of many schools that only carry out religious education only. On the one hand, it is a pesantren as an institution of excellence creators of the "ulama", but if we keep abreast of the times and the needs of society in general, the education contributes on the character and professionalism of individuals, should walk hand in hand with the development of world.

Lately the pesantren provides various types and levels of education, including promoting Isamic Senior High School or Madrasah Aliyah. As described by Azra, in addition to equip students with the knowledge and the formation of character, Madrasah Aliyah (MA) also emphasizes the formation and development of skills that are now popular with the term lifeskills [4].

In the field of education, some pesantren can be said to compete in offering a competitive education model capable of generating graduate students who have competence in mastery of knowledge as well as skill (skill) so that it can be a provision to plunge into a social life that continues to 
accelerate change Due to the modernization sustained by the sophistication of science and technology.

Raudlotul Ulum is a "modern pesantren". As its name implies, it modernises pesantren education by introducing a structured grade system, classrooms, textbooks and an ethos of reform and progress. It became modern because the educational management based on the government's management, but still exist on the nature of pesantren itself [5].

Islamic Senior High School or Madrasah Aliyah (MA) is an educational institution that provides education and teaching upper secondary level under the auspices of the ministry of religion and made the subject of Islam as the basic subjects in addition to general subjects. The pressure on madrasah was increasing based on the requirements of controlling between the science and Islamic education.

Management education in pesantrens, especially Madrasah Aliyah urgently is need to be developed, through openness schools produce people who are basically possible, but also an intellectual cleric insightful. There are 4 renewal in schools: First, the renewal of the substance or content of pesantren education to include general subjects and vocational; second, the update methodologies, such as the classical system, hierarchy; Third, institutional reform, such as pesantren leadership, diversification of educational institutions; and fourth, the renewal functions of the educational function including socio-economic function [4].

Educational Management of Madrasah Aliyah in pesantren is the process of managing educational institutions Madrasah Aliyah who are in pesantren by empowering potential of existing resources to achieve educational goals effectively and efficiently. The problems on slow progress of education in pesantren will be solved by some developments on the education management.

Roudlotul Ulum is a pesantren that manage formal education starting from diniyah, madrasah and Madrasah Aliyah. Roudlotul Ulum management combines the ministry management and pesantren management in one place or boarding. It is a pesantren which has many development of education management so that the objective of education in pesantren is fulfilled related to the objection of education in Indonesia.

The education management of Islamic Senior High school in pesantren Raudlotul Ulum has the unique management of education to be researched. The unique are the mixing of curriculum; between the national curriculum and the pesantren curriculum. The final examination of the students is also kind of the unique management in pesantren Raudlotul Ulum. All those will described in detail below.

This objective of this study is finding the differences between the management of Madrasah Aliyah and pesantren and whether there should be the relation between the two managements. How is the management of Madrasah Aliyah in pesantren Raudlotul Ulum?, How is the different between its management and the general management of Madrasah Aliyah?. The result of this research is supposed to be used as a reference in developing management of Madrasah Aliyah in pesantrens as a whole, because there are many Islamic educational management Madrasah Aliyah in schools in underdeveloped and needs to be addressed.

\section{METHOD}

This study aimed to gain a deeper understanding of management education in Madrasah Aliyah Raudlatul Ulum pesantren. In this regard researchers using qualitative methods. It is aimed to understand the phenomenon of what experienced by the research subjects, such as behavior, perception, motivation, etc [6].

The qualitative researchers should be able to give meaning to the facts obtained from the study site. He also intended to express and understand the new data about the phenomenon that is difficult to be expressed (Strauss and Corbin, 2009: 5). Particularly in the field of educational management Madrasah Aliyah as an object of study, the researcher's presence meant to assess the actual data as an object of research which is natural and growing, as well as researchers are not going to manipulate or add or remove data that is found from the study [2].

This research is descriptive, comparative and associative. It is designed to gain a deeper understanding of education management madrasah aliyah in Raudlatul Ulum boarding school by using analysis of descriptive study. The result is interpreted in the context of the time / certain situations. It is supported by the confirmation of some parties under the research investigation.

The data were gathered from the observations, interviews of stakeholders and the data from the boarding school institutions as supporting data. In depth analysis used to determine how the Islamic Madrasah education management in Raudlatul Ulum pesantren is.

Sources of data in this study can be divided into two; human and non human beings. Human sources function as the subject or key informants (key informants), from a variety of existing data on the exploration in accordance with the needs of research. While non human source is in the form of documents relevant to the focus of research, such as images, photographs, meeting notes or writings in connection with a research focus.

Determination of informants in this study are based on the following criteria: (1) The subject has considerable experience and intensive blend with the activity of the targeted research, (2) the subject is still involved in activities in the targeted research, (3) the subject has enough time to asked for the information, (4) the subject would provide the real information. There are 27 informants or respondents in this research, including the workforce, the chief of madrasah, the teachers, students and their parents, also the people around pesantren.

According to Mulyono, the scope of education management includes: 1) curriculum management, 2) management of management, 3) management of learners, 4) management of facilities and infrastructure, 5) financial management, 6) administrative management, 7) Management of educational support units, 8) special service management, 
9) environmental management and school security, and 10) management of community relations. [7]

From the theory above, the researcher focused on five elements of management. Then, the result of this study is broken down into five sub focus include: the Curriculum Management, Workforce Management, Student Management, Infrastructure Management, and Financial Management.

Data collection procedures used in this qualitative study is a review of documents, interviews, and observations. The data analysis on this qualitative research consists of three activities occurring simultaneously namely data reduction, data presentation, drawing conclusions or verification. The researcher conducted the interpretation of the data in the form of words, behavior, as well as documents in order to obtain the meaning (meaning).

Data analysis performed in this study, systematically arranged the interview transcripts, field notes, and documents that have been collected by researchers. Activity analysis is done by examining the data, organize, split into units, mansintesis, look for patterns, obtaining data that has meaning, and report the results of a systematic study [6]. The analysis is that the researcher conducted the interpretation of the data in the form of words, behavior, as well as documents in order to obtain the meaning.

The validity of the data in this research is based on four criteria; first is the degree of reliability (credibility). The researcher gained the more data by doing more observation on the target. The triangulation also was done to check the trust of the information gathered from the sources. Second is transferability which the researcher showed the detail description and interpretation of the data based on the results. Third, dependability was done to avoid any mistakes in the study. The researchers considered such data checks by considering other factors related to the context of the examination of the data. Fourth is certainty (confirmability) by confirming the data with the informants [8].

\section{RESULTS AND DISCUSSIONS}

Management is moving from the planning process, organizing, mobilization and supervision or controlling by determining the goals through utilization of human resources and other resources. Management as a process of stages that have to be done to achieve the goals set. (Pettalongi)

Education management limit operationally is proposed as follows [8]; (1) Management education is a form of cooperative education personnel to achieve educational goals, (2) Management education is a process of organizing education cycle starting from planning, followed by organizing, directing, implementing, monitoring, and assessment of school effort to achieve the objectives, (3) Education management is an effort to make the management of education system, (4) education management is to lead activities, decision-making and communication in school organization in an effort to achieve educational goals.
There is a close relationship between the rights to formulate goals with learning outcomes obtained. This shows that effective management can facilitate the achievement of educational goals [9]. An institution will gain of education by applying good management in the whole aspects of educations.

The goal of management from an Islamic perspective in Madrasah Aliyah Raudlotul Ulum is to serve others, prioritise the public interest over private interest and focus attention on spiritual and psychological aspects before physical aspects. This is the purpose of satisfying Allah (God) and relates to the demand of 'Reward' from him, as shown in the verse 'indeed, we will not allow to be lost the reward of any who did well in deeds [10].

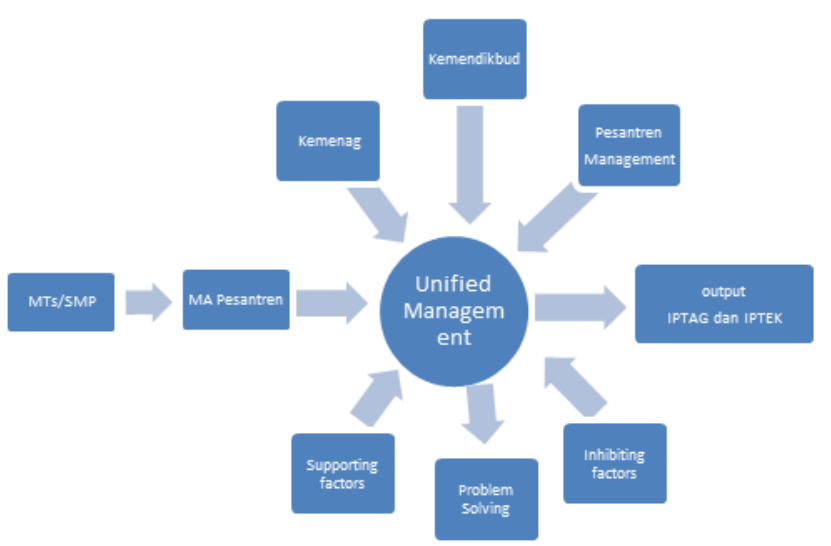

Fig. 1. 3 Integrated Management Institute

The results of this study described into five management applications in madrasah: the Curriculum Management, Workforce Management, Student Management, Infrastructure Management, and Financial Management. The descriptions are showed below:

\section{A. Curriculum Management}

Pesantren as one of the Islamic educational institutions also cannot be separated from changes and curriculum development. If applied in the curriculum of Islamic educational institutions, the curriculum serves as a guide used by educators to guide learners toward the highest goal of Islamic education, through the accumulation of a number of knowledge, skills and attitudes [11]

In 1951, Madrasah equipped its santri with non-religious subjects, such as English, Indonesian and Sociology, in compliance with a regulation issued by Ministry of Religious Affair. When the government offered the graduates of the madrasah 'the state educational certificate' based on the national exam, it declined. The acceptance of such an offer led 
to dependency of the madrasah's control over determining the best curriculum for its santri [13]. Madrasah aliyah in its development, raudlotul ulum with its pesantren has its own independency to determine the best curriculum for its santri, besides it still use national curriculum by the government.

Madrasahs are formally under the guidance of the Ministry of Religious Affairs. The education policy in the madrasah environment as a subsystem within the whole national education system is established not unlike the education policy set by the Minister of National Education. Therefore, the madrasah is given the limit as a public school characterized by the Islamic religion and managed by the Ministry of Religious Affairs. Madrasahs use the full curriculum, use the same package book, take the national exams together and follow the technical guidance instructions of the Ministry of National Education [12].

Pesantren-based curriculum planning involves several elements of madrasah aliyah including madrasah head, deputy head of the curriculum, deputy head of facilities and infrastructure, deputy head of student affairs, deputy head of public relations, BP coordinator, head of TU, and coordinator of madrasah committee. The curriculum planning of Madrasah Aliyah Raudlatul Ulum combines 3 curriculum, including Kemendikbud curriculum, Kemenag curriculum and pesantren curriculum (mulok). The local subjects of pesantren are:

TABLE 1. Local Content

\begin{tabular}{|c|l|l|}
\hline No & \multicolumn{1}{|c|}{ Subjects } & \multicolumn{1}{c|}{ Kitab } \\
\hline 1 & Fiqh & Fath al Wahhab \\
\hline 2 & Ushul al Fiqh & Ghayat al Wushul \\
\hline 3 & Ilmu al Balaghoh & Syarh Uqud al Juman \\
\hline 4 & Tafsir & Tafsir al Jalalain \\
\hline 5 & Qowaid al Fiqhiyyah & Faraidl al Bahiyyah \\
\hline 6 & Akhlaq & Maraqi al Ubudiyyah \\
\hline 7 & Hadist & Tajrid ash Shorih \\
\hline 8 & Tarikh Tasyri' & Tarikh at Tasyri' al Islamiy \\
\hline 9 & Ilmu Mantiq & Idhohul Mubham \\
\hline 10 & Ilmu Falak & Fath ar Rouf al Manan \\
\hline 11 & Ilmu Tafsir & $\begin{array}{l}\text { Ilmu Tafsir Imam As } \\
\text { Suyuthi }\end{array}$ \\
\hline
\end{tabular}

In the process of curriculum-based pesantren planning in Madrasah Aliyah Raudlatul Ulum there are several things done among others as follows:

\section{1) Setting Goals}

Setting goals is the most important thing to do in planning the curriculum. A good goal should be in accordance with the vision and mission of the madrasah.

\section{2) Determining Learning Materials}

The next thing to do is related to the structure of the curriculum content. The structure of the curriculum of Madrasah Aliyah Raudlatul Ulum includes the substance of learning taken in one level of education for three years from class X to class XII. The curriculum structure is structured according to the standard of graduation competency and subject competency standard.

The emergence of madrasah gained government attention, in 1946, in order to improve the quality of education in madrasah efforts to include seven general subjects which should be taught as a curricular program. This step was then followed up by the Ministry of Religious Affairs in 1958/1959 by introducing Mandatory Madrasah to study as one of the renewal efforts of the Madrasah education system [14]

Beside the Islamic subjects, the pesantren curriculum is also applied specifically to the local content curriculum. In addition to some subjects that have been mentioned above, Madrasah Aliyah Raudlatul Ulum added special subjects in the form of worship practices. This lesson contains commonly needed materials in society, such as the practice of reading maulid diba', tahlil, and khithobah.

In addition, the organization of curriculum in Madrasah Aliyah Raudlatul Ulum contains the following content: religious subjects and noble character, citizenship and personality, science and technology, aesthetics, and sports and physical education.

\section{3) Learning process}

The needs should be implemented in curriculum planning is the process of learning. Learning process in Madrasah Aliyah Raudlatul Ulum is applied by pesantren learning system. This has actually been done, since Madrasah Aliyah Raudlatul Ulum stands. This learning process is determined in the stage of curriculum planning so that later can be used as a guide at the stage of implementation of the curriculum.

\section{4) Curriculum Evaluation}

The evaluation of the curriculum aims to determine the extent to which learners understand or absorb the material that has been conveyed by educators. The evaluation of learning outcomes in Madrasah Aliyah Raudlatul Ulum has two forms of evaluation:

a. Imtihan is a test which is held twice a year on Jumadil Awwal and Sha'ban. Imtihan implemented for 2 weeks, a week for written test and another for oral test.

b. Munaqosah is reserved for class XII (twelve) held before the National Standard Madrasah Exam (UAMBN) and National Exam (UN) namely the consolidation of Local Content (mulok) material as one of the requirements of graduation. The material is memorizing Juz Amma, reading the Yellow Book, Arabic and English conversation.

The prominent findings of this curriculum management is the application of three evaluation exam of Madrasah Aliyah, those are; First, learners must pass the National Exam including Indonesian, English, Mathematics, Biology, Social Studies, and Economics corresponding respective majors. Secondly, learners must pass exams organized the National Standard Madrasah by the Ministry of Religious Subjects 
including Qur'an Hadist, Aqidah Akhlaq, Fiqh, Islamic Cultural History and Arabic. Thirdly, learners must pass the exam Munaqasah, including Qowaidul Fiqihiyah, Munaqosah Memorizing the Qur'an Juice Amma, read the Yellow Book, conversational Arabic, and English conversation. When holding munaqosyah exam, learners are examined by four examiners and one clerks in the test. The more unique finding, the researcher find that the students who passed the two examination; the National Examination and Madrasah, but they did not pass the local content examination, so they should do the examination until they can pass it well.

\section{B. Workforce Management}

Workforce Management Findings divided into two:

1) Educational staff consists of the unity of the Civil Servants, second is the group of the permanent and non-permanent teachers of Madrasah. Third, educational teachers stay together in one Institution of pesantren as needed and in accordance with their respective competences.

2) The teachers organized 3.950 students in pesantrens (including MA) and 2,000 students outside the pesantren environment. Meanwhile, management is focused on the Kyai (Cental Management) assisted by the teachers and senior students supported by systematically guidance.

The pesantren life is strongly characterized by hierarchical and patron-client relationship in which the kyai (pesantren religious scholar) represents a charismatic leader highly respected not only by santri (pesantren students), but also by the surrounding society [13]

Kiai positioned as a coach, equivalent to the founder, given the duty and authority remains very honorable, namely keeping the ideology of boarding school, making public policy, and fostering the Board and Supervisor. The coach has the right to appoint and dismiss the Board and the Supervisor. However, operational management issues are entirely left to the Board, and the supervisory duties are the responsibility of the supervisor. With the rules based on the Act, Kiai has no right to give instructions or direct intervention on the implementation of activities or units under the Board. Thus, now open the opportunity for boarding boarding school to apply modern management in accordance with his knowledge [15].

Associated with management, Pondok Pesantren with its diversity is included as unique institutions or educational organizations. Among others, because in boarding school there are Kiai figures that have exceptional roles and authority, until in the perspective of management science often occur contradictory or not in accordance with the code of ethics. For example, related to the delegation of duties and authority, level of power, the problem of intervention, and others. Nevertheless, there are also pondok pesantren that apply modern management with good [15].

The role of teachers or educators in madrasah aliyah is as follows: (1) Informators, implementers of informative teaching methods; (2) Organizers, managers of academic activities; (3) Motivators, improving activities and development of student learning activities; (4) Caregiver / director, that is guiding and directing student learning activities in accordance with the goals aspired; (5) Initiator, the originator of ideas in the learning process; (6) Transmitter, ie disseminator of education and knowledge policy; (7) Facilitator, ie providing facilities or facilities in teaching and learning process; (8) Mediator, intermediate in teaching and learning activities; (9) Evaluator, ie assessing the achievement of students in the field of academic and behavior [16]

In addition to the educators, madrasah aliyah Raudlatul Ulum get help by 2 educators from Egypt settled in the cottage 1 year running the next turn in the same amount. Similarly, in 2015, it also got the help of educators from America through the American ambassador in Indonesia (Jakarta). The educators from Egypt in Madrasah Raudlatul Ulum concurrently become the administrators of Madrasah Aliyah.

\section{Student Management}

The management of students of Madrasah Aliyah Raudlatul Ulum is an effort through student management activities to improve the quality of learning in Madrasah Aliyah Raudlatul Ulum. Student management is one of the important pillars that should get special attention on managing Madrasah Aliyah. The fundamental reason is that the management of the students is directly related to students in Maadrasah Aliyah, such as learners whose achievements are above average or otherwise.

Basically the system of admission of new students in Raudlatul Ulum Madrasah Aliyah, there are three mechanisms: First, regular Line learners are new graduates from the junior high school of Raudlotul ulum. Second, the special line (Mumtaz) is for the graduates of SMP / MTs from other schools. Third, the test line is for students graduated from junior high school / MTs from other schools who do not pass a special line.

In classifying santri, modern pesantren introduces a class system based on knowledge possessed, not on the number and type of books that have been studied. In addition, modern pesantren began to access technology as a means and a foreign language (especially Arabic and English) as the medium of instruction that allows students to communicate with intellectual communities in the outside world (Munawar 2001: 100).The acceptance of new students in Madrasah Aliyah Raudlatul Ulum, does not use age restrictions as in other formal schools, and is not limited its capacity, as for the requirements of students received are graduates of MTs Raudlatul Ulum or Mumtaz 2 graduate or pass the exam system.

The alumna of Raudlatul Ulum is able to compete competitively with other Madrasah alumnus. This is evidenced by the alumnus of Roudlotul Ulum Madrasah Aliyah are accepted at various universities in the country and abroad. As in Egypt's Al-Azhar University which annually receives 20 students from Raudlatul Ulum. In addition, many also are accepted at universities in the country, such as in the UI, UNDIP, UNNES and They are prepared to answer the needs of society, in general, namely for religious knowledge (IPTAG) and Science and Tekonologi (Science and 
Technology). It means that Roudlotul Ulum could compete with the other Madrasah Aliyah in the field of Religious Studies and other vocational high schools in the field of Science and Technology.

\section{Infrastructure Management}

Facilities and Infrastructure Planning of Madrasah Aliyah Raudlatul Ulum is done with the following things including: 1) holding a team meeting in advance of moving goods or not moving. In this team will be a procurement committee of Facilities and Infrastructure. In this meeting held the data about the needs of the madrasah span of one year, 2) Determine Facilities and Infrastructure needed, of course with a priority scale which in the arrangement based on the level of importance, besides facilities and Infrastructure is expensive, the following considerations are held: (3) the source of funds in the Planning of Infrastructure, sourced from government ie from BOS and DIPA funds. The main fund in the planning of Facilities and Infrastructure is more priority funding from BOS itself, and even then only for things that support the teaching and learning process and the needs of madrasah.

Organizing Facilities and Infrastructure at Madrasah Aliyah Raudlatul Ulum is done with the following things: 1) Distribution of Facilities and Infrastructure, for example goods are not consumed after purchased or received then the next step is to be matched letter introduction, then recorded to inventoried and coded, Year of goods received as well as sticker owner Raudlatul Ulum Foundation. 2) Distribution of consumables, which are distributed to users or to classes and that are still there are stored as stock of supplies.

Implementation of Facilities and Infrastructure at Madrasah Aliyah Raudlatul Ulum is done as well as described as follows: 1) implementation in terms of maintenance that is checking the Facilities and Infrastructure when purchasing, it must be checked in the store, after arriving at the madrassah the goods are checked back. For preventive maintenance, madrasah inventory items, such as printer repair, generator sets, and so on. The maintenance fund is sourced from Yayasan Raudlatul Ulum, in addition to minimizing the limited funds then also from BOS / DIPA. 2) repairing the facilities those are need to be repaired because of damage or broken.

In terms of evaluation of Facilities and Infrastructure, Madrasah Aliyah Raudlatul Ulum do the following: 1) Evaluation in terms of inventorying Facilities and Infrastructure, Firstly, there are some inventory belonging Madrasah aliyah Raudlatul Ulum brought by educator or educational staff, The person has been transferred to another madrasah, the carrying goods are notebook / laptop. 2) The number of inventory code of goods lost on the goods belonging to the madrasah inventory is due to the sticker attached to the item is long enough, plus the student behavior that tore the sticker.

The efforts made by the madrasah are: First, make a notice to the holder of goods to immediately deliver the goods to the madrasah. Secondly, the future will re-identify the goods whose goods inventory code no longer exists. 2) Elimination of goods and services, when in the implementation of
Facilities and Infrastructure there is a problem because of the very large number and quantity of goods and services, it is required Deletion. This removal is done when there is inappropriate usage or it does not need to be used.

Program evaluation is a unit or unit of activity aimed at gathering information about the realization or implementation of a policy, takes place in a continuous process, and occurs within an organization involving a group of people for decision making [16].

\section{E. Financial Management}

The main financial is managed from all madrasah shelter in Raudlatul Ulum Islamic Pesantren Foundation. The financial resources are from Operational Assistance (BOS) by the government routinely, cooperative outcomes and results by the hospital. For the purposes of Raudlatul Ulum Madrasah Aliyah, it is no need to get the donations from the learner's parent because the financial resources are managed intensively so that the learning always runs smoothly.

Madrasah Aliyah Raudlatul Ulum in planning for madrasah finance includes two activities undertaken by madrasah namely:

\section{Arrangement of Estimation Plan of Madrasah Revenue} and Expenditure.

Budget in Madrasah Aliyah Raudlatul Ulum is an income and expenditure plan that is used as a guide in carrying out the activities of the institution within the next one year. Therefore, in the budgeting of Madrasah Aliyah Raudlatul Ulum there is a description of the need to perform activities that will be implemented by madrasah within the next one year.

Budget arrangement is a process of negotiation or agreement between the top leadership with the leadership below it in determining the amount of budget allocation budgeting. The final outcome of the negotiation process is a statement of expected expenditure and income from each funding source. In the arrangement of the budget in Madrasah Aliyah Raudlatul Ulum, Director assisted Assistant Director to negotiate through meetings especially at the end of the budget year. The negotiations are used to determine the amount of cost allocations required to implement the program to be developed.

2. Development of Budget Plan for Revenue and Expenditure of Madrasah

In conducting the RAPBM development, the working group determines what programs at the beginning of the year to the end of the year with the priority of the predetermined costs then received approval from the Director. In the implementation of such programs before each assistant director of each field of education has made a draft program of activities then submitted to the Director for approval. After the activity program is approved then the allocation of funds can be implemented.

After the planning is completed and approved by all parties involved, then the next step in management is the implementation of the planning that has been made. In the financial implementation Raudlatul Ulum Madrasah Aliyah 
madrasas do two types of activities: the acceptance and expenditures of funds for education.

Next is Madrasah Financial Evaluation is a tool to measure costs after planning is established. This evaluation functioned as a step in controlling the planning and implementation of madrasah finance. After supervision and examination is done, the next process is the accountability of madrasah finance to the receipts and expenditures that are recorded in RAPBM format then annually reported to the Director of Madrasah Aliyah Raudlatul Ulum.

\section{CONCLUSION}

Education Management Raudlatul Ulum Madrasah Aliyah including a central figure category (Kyai) is not similar to the management of education in general. However, it has good quality compared with the others Madrasah Aliyah. The similarity between Raudlotul ulum and others is the management of Kemendikbud and MORA curriculum, but it has local content subjects (Mulok) which show its different in learning process.

The management of workforce Madrasah Aliyah Raudlatul Ulum has 78 educators and education personnel, with details of 3 Teacher aids MORA (PNS), 63 teachers remained Foundation and 9 teachers do not remain the Foundation as well as 3 educators (Document MA Raudlatul Ulum, 2016). Educators and education personnel are placed in accordance with their respective expertise. However, coaching and skill development educators have not been implemented optimally. Except that, staff were not kept stocked Foundation alumni who have completed S1 served for one year in turn.

Learner's management is performed with Madrasah needs analysis, placement and grouping of students, recording activities in activities and evaluation, also follow-up. In the development of students' potentials optimally performed with a test to know the character, talents and interests in academic and in addition to the development of co-curricular, activities (extracurricular), such as the sports talent development, Pencak Silat, Scouts, Marching Band and others.

Infrastructure management in private institutions, especially Madrasah Aliyah in boarding, building or other facility acquisition in addition to his own efforts had also received support from the central government and local government. This is done in accordance with the needs of learners infrastructure that needs infrastructure with learners can be balanced. If there is an urgent need for the means (urgency) such as Computer Based Exam, field infrastructure will pursue these needs can be met.

The author has found a blend of three managements of MORA agencies, organizations and educational institutions Kemendikbud Madrasah Aliyah in pesantren. The combination of this management resulted in outcomes learners be equipped by Religious Sciences (IPTAG) and Science and Technology into embryonic cadre character Nation cultures and religions are capable of international competitiveness.

The findings of the research can be applied in this integrated management applies to all managers Madrasah Aliyah in Madrasah Aliyah pesantren or managers who do not at pesantren, also manager of public and private high school institution or equivalent.

\section{ACKNOWLEDGMENT}

I would like to express my sincere thanks especially to KH. MA. Ahmad Sahal Mahfudl as Rector of UNISNU, KH. Drs. Najib Suyuthi, M. Ag as caretaker (kyai) of pesantren and Head of Madrasah Aliyah Raudlatul Ulum Guyangan gave the permission for completing this research. All teachers and staff boards along with the Raudlatul Ulum Guyangan have been willing to cooperate and contribute on this research.

\section{REFERENCES}

[1] Zakiyah, Qiqi Yuliati \& Rusdiana A. Pendidikan Nilai: Kajian Teori dan Praktek di Sekolah. Bandung: Pustaka Setia. 2014.

[2] Murtadho, M. Pesantren Salaf dan Perubahan Sosial: Studi Kasus pesantren Al-Anwar Sarang Rembang. Edukasi Jurnal Penelitian Pendidikan Agama dan Keagamaan, Vol. 10, Number 1, 2012.

[3] Khasan, Moh. Pesantren, Sufisme dan Tantangan Modernitas. Dimas Jurnal Pemikiran Agama untuk Pemberdayaan, Vol. 10, Number 1, 2010.

[4] Azra, Azyumardi. "Modernisasi Pendidikan dan Pesantren," dalam Idris Thaha, (Ed.). Pendidikan Islam Tradisi dan Modernisasi di Tengah Tantangan Millenium III. Jakarta: Kencana. 2012.

[5] Charlene Tan. Educative Tradition and Islamic Schools in Indonesia. Journal of Arabic and Islamic Studies, 14: 47-62, 2014.

[6] Moleong, Lexy J. Metodologi Penelitian Kualitatif. Bandung : PT Remaja Rosdakarya. 2013.

[7] Mulyono. Manajemen dan Organisasi Pendidikan. Jogjakarta: ArRuzz Media. 2008

[8] Suryabrata, S. Proses Belajar Mengajar di Perguruan Tinggi. Yogyakarta: Andi Offset. 2008.

[9] Huang, C. Discriminant and Criterion Related Validity Of Achievement Goals in Predicting Academic Achievement: A Meta Analysis. Journal of Educational Psychology. 104-1, 2012.

[10] Alkrdem, M. S. and Alqahtani, A.S. Educational Management in the Light of Islamic Standards. British Journal of Education, Society \& Behavioural Science. 14(3): 1-9, 2016.

[11] Shofa, R. A. Kurikulum dan Dinamika Perubahannya di Pondok Pesantren. Manageria: Jurnal Manajemen Pendidikan Islam, Volume I, Nomor 1, 2016.

[12] Masnun, Moh. Implementasi Kurikulum Madrasah dengan Pendekatan transmisi, Transaksi, dan Transformasi. Al-tarbiyah. Vol.23, Number 1, 2010.

[13] Budiwiranto, B. Pesantren and Participatory Development: the Case of the Pesantren Maslakul Huda of Kajen, Pati, Central Java. Journal of Indonesian Islam, Vol. 03, Number 02, 2009.

[14] Khafidin, Zaenal. Model pendidikan Pesantren Madrasah. Jurnal Penelitian Islam Empirik, Vol. 2, Number 1, 2008.

[15] Asifudin, A. Janan. Manajemen Pendidikan untuk Pondok Pesantren . Manageria: Jurnal Manajemen Pendidikan Islam, Volume 1, Nomor 2, 2016.

[16] Miswanto. Evaluasi Pelaksanaan Pendidikan Pesantren Mini di Madrasah Aliyah Patra Mandiri Plaju Palembang. Jurnal of Islamic Education Management, Vol. 2 No. 2, pp 86-104, 2016.

[17] Munawwar, Abdul. Belajar Dari Keajegan Proses Pembelajaran Di Pesantren. Seri XI Lectur STAIN Cirebon, 2001. 
[18] Nata, Abuddin. Manajemen Pendidikan: Mengatasi Kelemahan Pendidikan Islam di Indonesia. Jakarta: Kencana. 2010

[19] Pettalongi, Sagaf S. Education Management Analysis of Sayid Idrus Bin Salim Aljufri to Develop Education Institutions (19301969). Australian Journal of Basic and Applied Sciences, 9(11) 2015, Pages: 981-989.

[20] Strauss, Anselm \& Juliet Corbin. Dasar-dasar Penelitian Kualitatif. Yogyakarta: Pustaka Pelajar. 2009.

[21] Sugiyono. Metode Penelitian Kualitatif, Kuantitatif, dan Kombinasi (Mixed Methods). Yogyakarta : Alfabeta. 2011. 